Article

\title{
Large Landholdings in Brabant: Unravelling Urbanization Processes in the City-Territory
}

\author{
Guillaume Vanneste \\ Faculty of Architecture, Architectural Engineering and Urban Planning (LOCI), UCLouvain, 1348 Louvain-la-Neuve, Belgium; \\ E-Mail: guillaume.vanneste@uclouvain.be
}

Submitted: 15 January 2020 | Accepted: 11 May 2020 | Published: 30 June 2020

\begin{abstract}
Through the observation of land property (le foncier) and, specifically, large landholdings, this research aims to take a fresh look at urbanization and urban planning in the Belgian Walloon Brabant Province. In contrast with most Belgian urban studies that tackle the issue of sprawling urbanization through small-scale parcels, fragmentation processes and individual initiatives, this investigation complements recent research on estate urbanization by examining large-scale properties and how they played a role in the city-territory's urbanization during the second half of the 20th century. Large landholdings in Walloon Brabant are remnants of 18th century territorial dominions inherited from nobility and clergy, progressively dismantled, reorganized or maintained as result of the urbanization dynamics integral to the reproduction of modern and contemporary society. The village of Rixensart is the subject of a series of these transformations. By mapping the de Merode family's large landholdings in the south of the commune and analyzing the allotments permit, we retrace urban transformations and the reordering of social and ecological relations through changing land structure. The palimpsest notion is used as a tool to unravel the set of actors involved in urbanization dynamics and to highlight the socio-spatial transformations and construction of recent urbanization. The profound transformations taking place in Walloon Brabant today present an opportunity to reflect on its future, and questions regarding landed estates suggest potential for tackling the city-territory's greater systemic challenges.
\end{abstract}

\section{Keywords}

Brabant; de Merode; dispersion; foncier; land; land ownership; landholdings; metropolization; property

\section{Issue}

This article is part of the issue "Territories in Time: Mapping Palimpsest Horizons" edited by Chiara Cavalieri (UCLouvain, Belgium) and Elena Cogato (EPFL, Switzerland).

(C) 2020 by the author; licensee Cogitatio (Lisbon, Portugal). This article is licensed under a Creative Commons Attribution 4.0 International License (CC BY).

\section{Introduction}

Since the 1980s, the specific urban realm coined as the diffuse city (Indovina, 1990) has been the subject of many urban studies. Our research is rooted in the Belgian urbanism research field, in which a series of concepts have been developed such as the Radiant Suburb (Smets, 1986), urbanization without urbanism (Grosjean, 2010), and the horizontal metropolis (Secchi \& Viganò, 2012). The last was addressed by many researchers focusing on contemporary urbanization and urbanism in a descriptive manner; they investigated the production of the built environment as being a result of multiple processes of urbanization (Dehaene, 2018), itself the product of fragmentation, individual initiatives (De Meulder, Schreurs, Cock, \& Notteboom, 2009; Dehaene, 2013; Grosjean, 2010; Uyttenhove, 2011), and specific infrastructure and networks (De Block, 2011; De Block \& Polasky, 2011; Peleman, 2013; Ryckewaert, 2011). Although our topic is part of this epistemological movement, it corresponds to a collective interest that has emerged more recently and that lies at the interface between urban history through the analysis of changes in land structures (Corboz, 1983, 1993) and the analysis of a social geography (Babar, 2015; Zitouni, 2010). More recent research shows a converging interest in other forms related to the urbanization of large estates and noble and aristocratic domains. This work on land transforma- 
tions processes linked to the large estate was initiated for Brussels or Antwerp (Babar, 2015; May, 2018; Wambecq, 2019; Zitouni, 2010). The specific contribution of our research concerns the urbanization processes of estate urbanization in the territory of Walloon Brabant.

In continuity with this corpus, we investigate Walloon Brabant territory as historically comprised of large domains and landholdings that belonged to the nobility and aristocracy, the clerical order, and the Church or industrial and bourgeois landlords. Large landholdings or estate operations are examined to determine which constitutive role they played in metropolization processes in the production of the spatial and material conditions of urbanization. Building on cases of these estates' transformation, we aim to explore the production of urbanization in Walloon Brabant for a specific spatial configuration. Among the cases, we encounter a variety of situations: allotment, businesses, industrial areas, and preserved green elements such as forest, golf courses, etc. (see Figure 1 and Table 1). This article highlights one of those situations and explores the type of urbanization produced after some large noble land holdings in Rixensart were dismantled. While leaving the unbuilt domains for further development, we will focus on built estates and their progressive urbanization.

From this overview, we formulate hypotheses and preliminary questions. Does the size of these landholdings generate a different form of urbanization? If urbanization has not been underpinned by an emancipatory political will to grant ownership access to middle-class households but is rather the result of reproduction processes driven by a social group or economic force, can we identify the intermediate actors and their role? If urbanization occurred by dividing an area via one consistent operation, as opposed to a parcel by parcel fragmentation, what were the necessary elements of negotiation between actors of urbanization (landlords, buyers, municipalities, provinces) and did they define the material conditions of such urbanization? Then, within the specific spatial condition of dispersion mentioned above, to

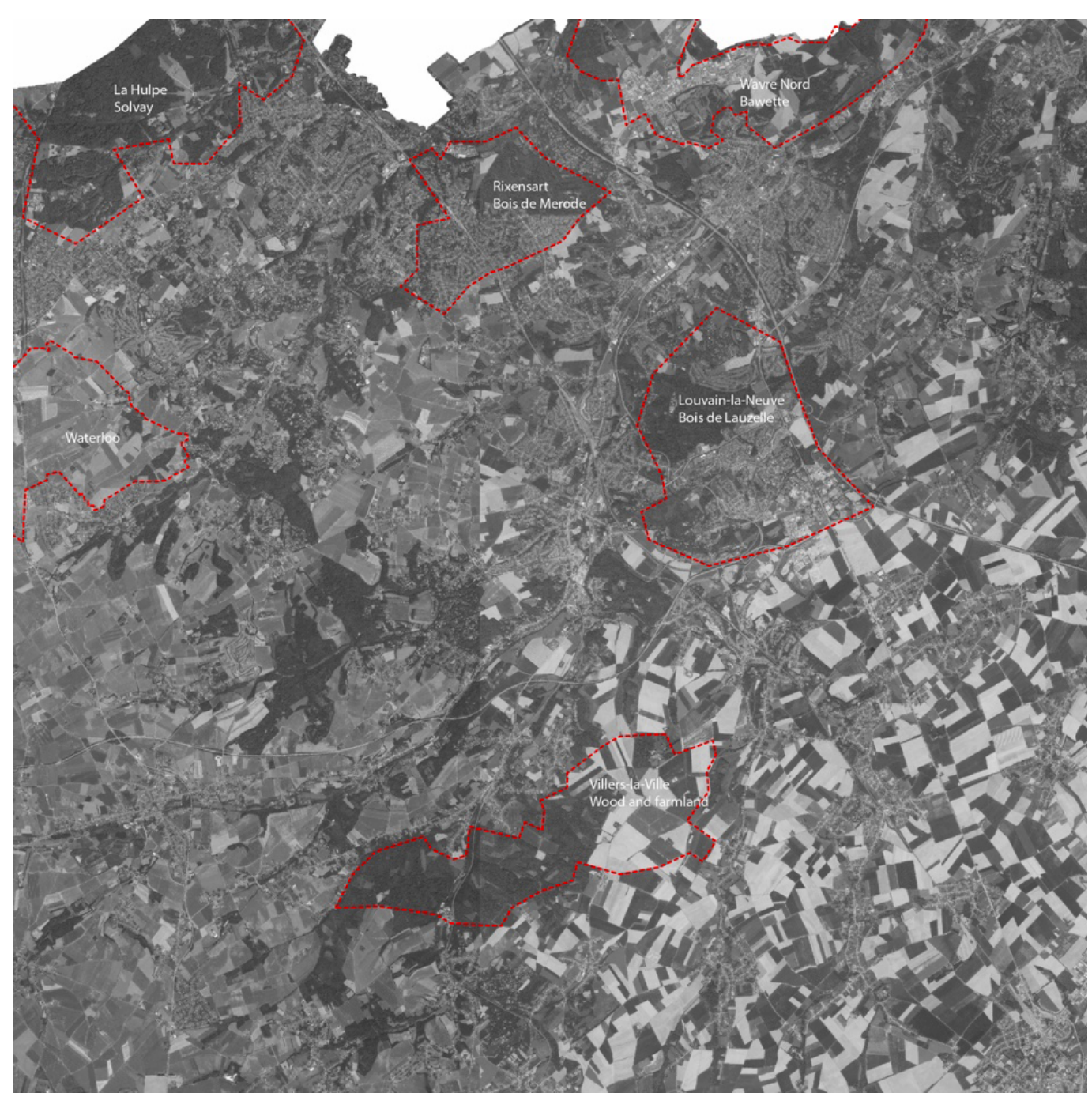

Figure 1. Selection of former noble large land holdings in Walloon Brabant, square of $20 \times 20 \mathrm{~km}$. Drawing by the author based on Popp [ca. 1854], Meuwissen (1994), the lotissements dataset (SPW-DG04, 2020) and the orthophotoplan (SPW-DG04, 2018). 
Table 1. Selection of former noble large land holdings in Walloon Brabant and their urbanization.

\begin{tabular}{|c|c|c|}
\hline Large estate localization & Urbanization & Continuous or fragmented \\
\hline Wavre Nord/Bawette domain & $\begin{array}{l}\text { Urbanized: economic activities and tertiary } \\
\text { area, golf course }\end{array}$ & $\begin{array}{l}\text { Continuous: golf } \\
\text { Fragmented: activities }\end{array}$ \\
\hline Rixensart/de Merode ownership & $\begin{array}{l}\text { Urbanized: residential allotments } \\
\text { Not urbanized: Bois de Rixensart }\end{array}$ & $\begin{array}{l}\text { Continuous: wood } \\
\text { Fragmented: residential allotments }\end{array}$ \\
\hline $\begin{array}{l}\text { Louvain-La-Neuve/D'Hoogvorst } \\
\text { ownership }\end{array}$ & Urbanized: new town & Fragmented: mixed functions \\
\hline Waterloo/Battlefield Waterloo & Not urbanized: Battlefield of Waterloo & Continuous: tenant farming \\
\hline Villers/Abbey & $\begin{array}{l}\text { Urbanized: abbey } \\
\text { Not urbanized: agricultural fields }\end{array}$ & Continuous: agricultural lands \\
\hline La Hulpe/Domaine Solvay & $\begin{array}{l}\text { Urbanized: La Hulpe Park and pharmaceutical } \\
\text { industries }\end{array}$ & $\begin{array}{l}\text { Continuous: park } \\
\text { Fragmented: industries }\end{array}$ \\
\hline
\end{tabular}

what extent do these large landownership urbanizations articulate themselves either to a metropolitan figure or to the one of a city territory?

\section{Land Ownership and Its Influence on Urbanization}

Land ownership and its parcel division is taken as the vantage point to describe the urbanization of this part of the Brabant. Why ownership? The history of urbanism and urbanization in Belgium is strongly linked to private ownership policies and the development of specific imaginaries around the ideal figure of the owner. Already during the Industrial Revolution, the 1889 owner-worker's law proposed an incentive system for workers to become owners in rural areas (Grosjean, 2010; Mougenot, 1999; Smets, 1977). After World War II, new policies for home ownership were supported by De Taeye Law of 1948, illustrated in Smets (1986), which describes the consumptive context of the Golden Sixties (les trentes glorieuses). Meanwhile, land or home ownership and the liberal construction of society based on non-selective private and individual initiatives supported by selective national infrastructure policies are the core of the Belgian narrative of urbanization (Dehaene, 2013).

The study of property is particularly rich owing to the latter's complex and polysemous aspects (Bernard, 2017; Vanuxem, 2018). Property, as a bundle of rights, combines several understandings linked to the plural realm of its definition: as land (relation to soil, its use and value), as a social item (relation to owners, social groups and their regulation by law), as a morphological element (plot, matrix and forms, their permanence and transformation), and as a territorial system (territorial domination of social groups, possession and accumulation). This polysemous meaning led us to read ownership and its transformation in an urban manner. Alongside the history of properties, one can read the history of ownership, unveiling societal relations and the balance of power between social groups. The territory is then investigated as a societal product (Corboz, 1983), a construction resulting from the actions of its inhabitants and their power relations. Large estates were most often owned by dominant groups such as the nobility, ancien régime clergy, followed by bourgeoisie and capitalist forces. Their construction or dismantling are the signs of social changes through economic mechanisms and negotiations between various actors in a society. Within the urban development of the metropolis, these signs also highlight conservation, speculation or migration between the so-called center and periphery.

We investigate estate urbanization on a regional scale within the frame of a city-territory (Piccinato, Quilici, \& Tafuri, 1962). The village of Rixensart is the context of a large series of these land ownership transformations. As for a dense city such as Brussels, the landholdings' reconfigurations occur through incremental processes (Babar, 2015) and lead to negotiated planning (Zitouni, 2010). The description of the social geography helps to qualify the material condition resulting from this urbanization process. In Rixensart, the de Merode family's landholdings will serve to describe a palimpsest of urbanization through relations between actors and land processes.

\section{Building the Unbuilt Patrimonial Estates: The Case of Rixensart}

Rixensart, a former village and now a municipality in Walloon Brabant, is located on the southern outskirts of the Brussels metropolitan region, in a continually urbanizing area serviced by the trains of the Brussels Regional Express Network. The Walloon Brabant is often described as a peripheral region of Brussels, home to a wealthy population who wanted to escape the metropolis. Originally constructed upon the rural and light industrial structures belonging to a fiefdom of several noble, aristocratic, and bourgeois landowner families (Hanin, 2004; Meuwissen, 1994), the Walloon Brabant is currently experiencing intensifying processes of metropolization and their direct and collateral effects: rising real estate values, construction of new mobility 
infrastructure and congestion of existing ones, pressure on and disappearance of farmland, and spatial inequity (Halleux, 2013; Hanin, 2012).

\subsection{Area South of Brussels}

The Walloon municipalities to the south of the Brussels Region have long been a typical example (Grosjean, 2010; Hanin, 2012; Puissant, 1997; Seebohm Rowntree, 1910; Vandervelde, 1900). Indeed, processes of urbanization in Rixensart were described when Emile Vandervelde (1900) selected it as a study case of the growing influence of Brussels on the Brabant Region (see Figure 2). While covering thoroughly land ownership in Belgium and Brabant with sharp datasets, Vandervelde showed two parallel trends driven by capitalistic forces: the fragmentation of property and the reinforcement of large landholdings. Indeed, the development of railway infrastructure caused speculation on the land for the growing metropolis of Brussels. Furthermore, southeast Brussels is historically linked to the territories of owners who inhabited villages and properties near the Sonian Forest and its former lumber yards, comprised mainly of nobles and clerical groups (Génicot, 1973; Hasquin, 1976).

\subsection{Land Ownership and Governance}

In the 18th century, Rixensart was the fief of a branch of de Merode's family (the Felix de Merode branch), a historic family of Belgian nobility. After the ancien régime during the 19th and 20th centuries, the municipality remained under the strong influence of the de Merode family, who owned much of the village and governed it via a mainly Catholic dynasty of Bourgmestre-Régisseurs (mayor/estate-stewards). Instituting a concordance of private land ownership and public governance in the municipality, they strictly controlled land use and therefore society. Thus, Rixensart's case reveals strong links between nobility, industrialization, municipalism, and land ownership structure modifications.

As a consequence of inheritance, de Merode lands were divided among several family members. After Félix de Merode's death in 1943, each of nine heirs inherited part of the whole. It was the first time the family's land was clearly divided and, while some holdings had already been sold in the early 20th century, they now began selling more of it, especially in the 1960s. All in all, de Merode property, a combined 537 hectares that represented two-thirds of the municipality in 1834, were reduced to 128 hectares by the 2000s (Meuwissen, 2016). In Section 5, we will investigate relations between sellers and buyers and the property's rearrangement.

\subsection{Production of Urbanization}

De Merode's land division occurs after the De Taeye Law of 1948, one of the most important post-war rebuilding and housing policies. At individual and private level, it provided incentives and subsidies to encourage private construction among the low-income population. Mortgage loans were made mostly through loan companies such as Caisse Générale d'Épargne et de Retraite and the Société Nationale des Habitations à Bon Marché. The law is regarded as a Catholic government effort to

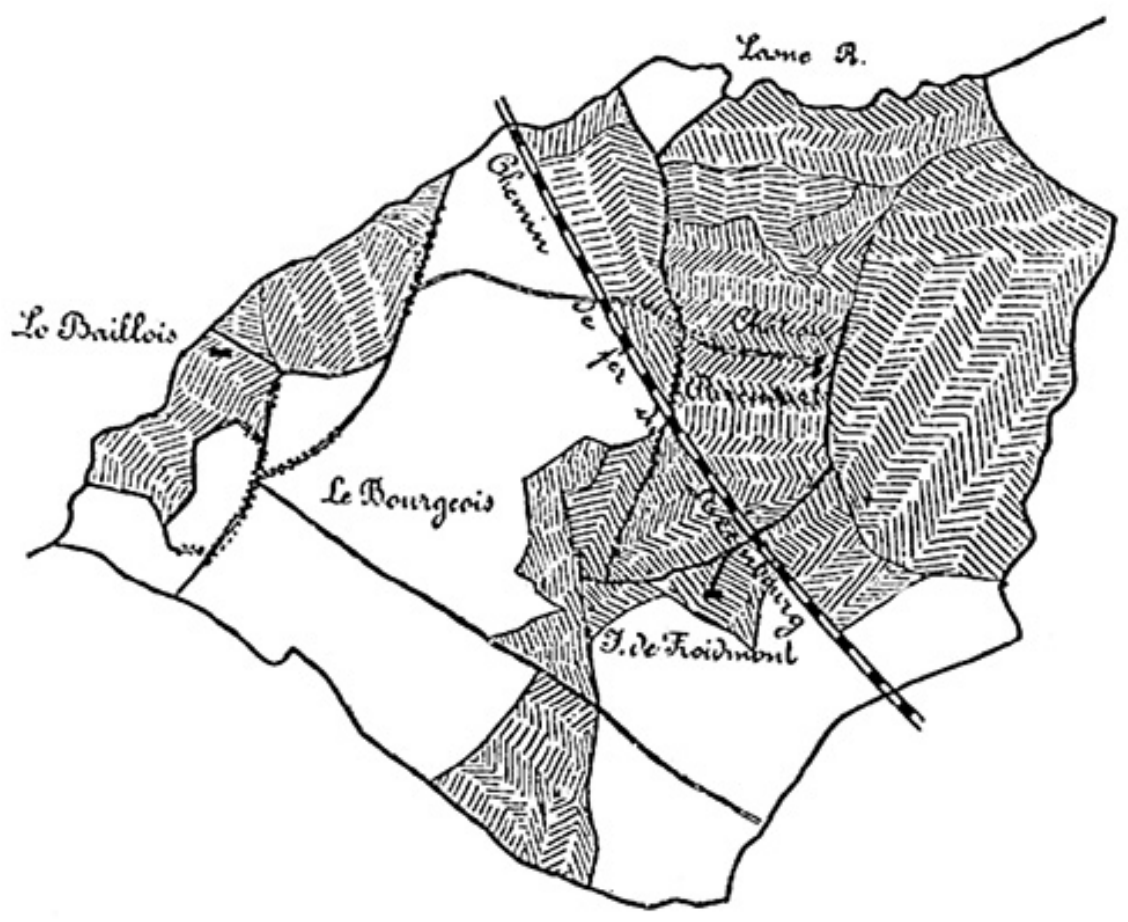

Figure 2. De Merode's properties in Rixensart municipality (gray areas). Source: Vandervelde (1900). 
keep village populations close to churches (Smets, 1985; Theunis, 2007).

The period coincides with the socio-economic context of the Golden Sixties and the implementation of the modern planning policy in the law of 29 May 1962, which is the founding basis of institutionalized urban planning as we mostly still know it, dedicating areas to specific land use under a strong functionalist assumption (Grulois, 2011). This resulted in a crucial moment in Rixensart's urbanization: the building of most of its current urban structure and material condition. Indeed, a large amount of the buildable parcels were then subdivided through allotment permit, a procedure defined in the 1962 law, creating large residential areas available for upper and middle-class populations. Various allotments south of the municipality are paradigmatic of this process, congruent with de Merode landholdings close to the train station and not far from the highway, in close relation with the growing Brussel metropolis. Whether Rixensart is a combination and specific result of both conjectural laws remains to be verified, since De Taeye's operational scale acts at an individual level. We rather insist here on larger allotment operations and more liberal socalled uncontrolled estate operations. Nevertheless, we will see that municipal and regional administrations proceeded quite consciously to produce urbanization.

\subsection{Urbanistic Regulations}

One hypothesis is that urbanistic policies were very permissive during the first years of their implementation (Laconte, 2012). Furthermore, some of the sales and trading operations occurred before urban planning and planning tools emerged and became institutionalized in Belgium-land use plans that were announced in the 1962 law were only operational in the 1980s. In the meantime, allotment and building permits (see Figure 3 ) fulfilled almost by default the role of more systemic plans or urban policies that were not yet elaborated. Most decisions were municipal, supervised by provincial or regional authorities, since permit authorizations were delivered, except in specific cases, under the municipality's responsibility after considering the advice of a regional delegated agent known as le fonctionnaire délégué (prefiguring the balance of power between municipality and region in Belgian urban planning). Administrative permit documents help us to deepen the analysis and set up a grid, although allotment plans control some limited parameters: plot dimensions, setback distances, alignments, façade cladding and roof coverings, trees, and plantations, and in some cases density. Regarding the quantitative output the permits dealt with, we find few limitations or constraints driven by more collective, ecological or political rationalities.

\section{Mapping the Estates: A Descriptive Analysis}

Among the domains that were sold, we limited our examination to seven allotments on former noble landholdings in Rixensart, chosen for their large size and period of development: Léopold and Blanc Champ Avenues, Clos de la Mare au Loup, Albertine and Churchill Avenues, the Froidmont Farm neighborhood (Winterberg Avenue), Hauts-Taillis Avenue, and Fond Marie Monseu (Figure 4). Popp's [ca. 1854] map and cadastral matrix, the first covering systematically the Belgian territory (in 1861 for Rixensart; see Vrielinck, 2018), were used to identify de Merode properties. Today, allotment permits are collected in a GIS layer by the Service Public de Wallonie. Original plans, allotment permits, and legal prescriptions are accessible for each perimeter. More than a century separates the two maps, but the unaltered structure of ownership until the first half of the 20th century (Meuwissen, 2016) allows us to proceed with this

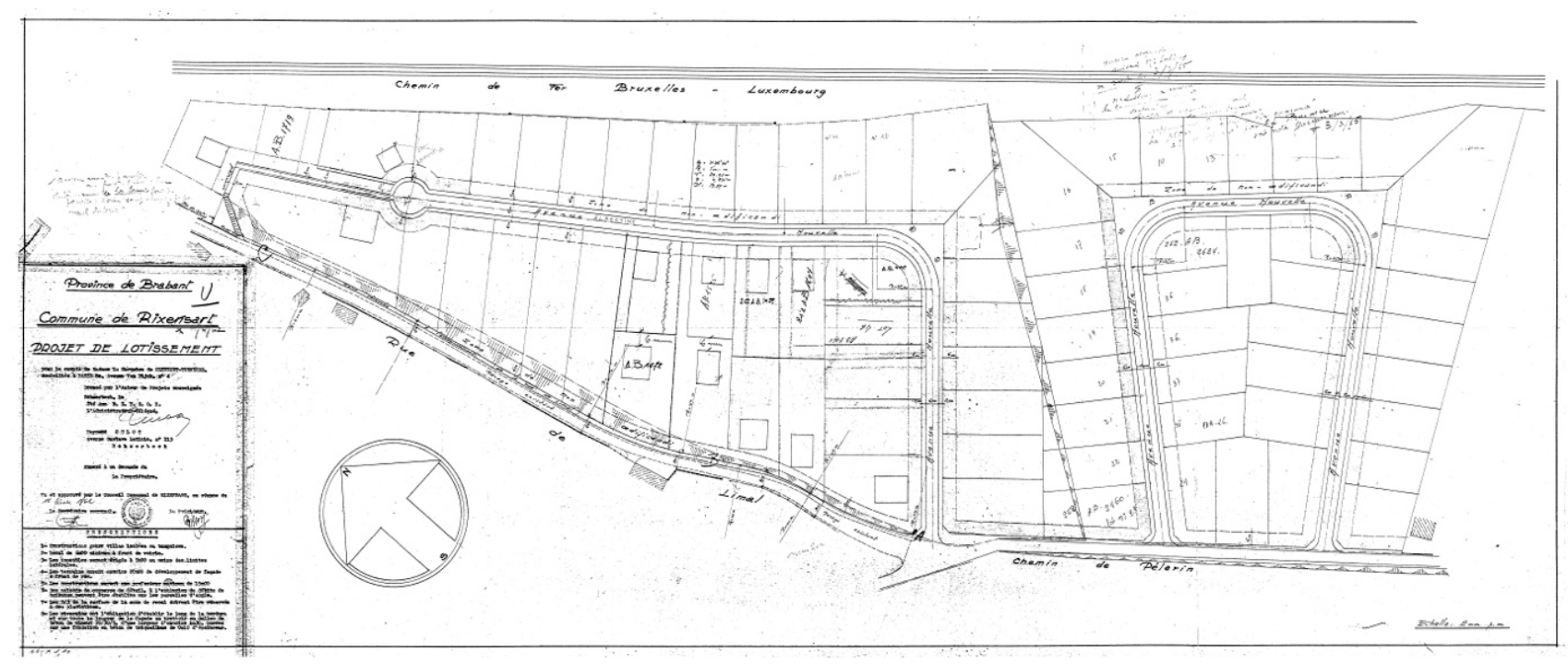

Figure 3. Example of a Rixensart allotment plan, Albertine, 1962. Source: Service Public de Wallonie, Lotissements (SPW-DG04, 2020). 


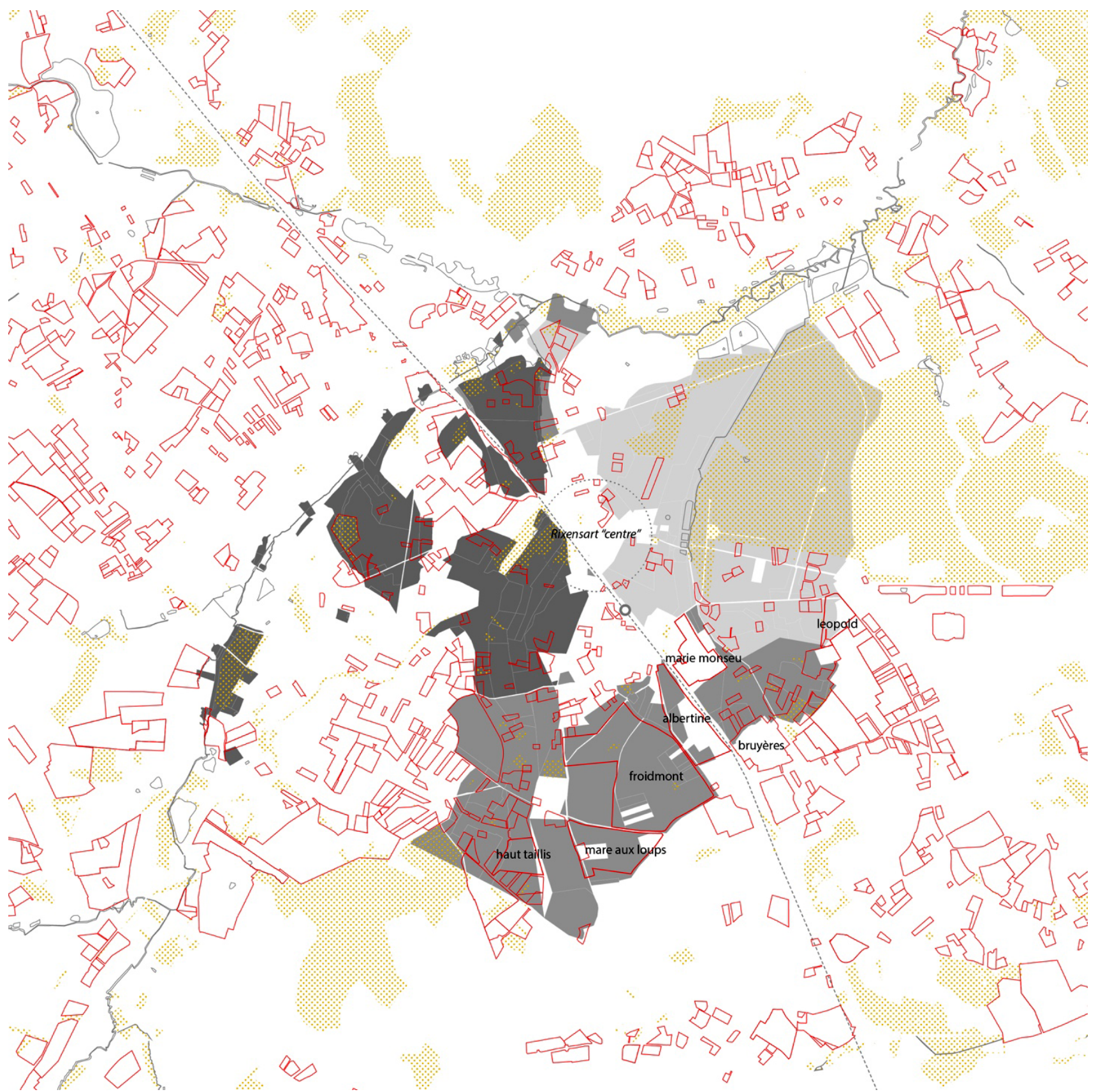

Figure 4. Cadastral map of Rixensart in 1854 with overlapping of allotments permit in 2019, de Merode properties. Dark gray areas represent the property of de Montalembert; gray areas, the property of Albertine de Merode; light grays, the property of Frédéric de Merode; red perimeters represent subdivision permits; yellow dots, the forest areas. Drawing by the author based on Popp [ca. 1854] and the lotissements dataset (SPW-DG04, 2020).

comparison. Table 2 lists the characteristics of the seven allotments. Allotment reference, date of authorization, owner, estate company (if any), parcel size, location, and main prescriptions are indicated. Altogether, they represent 67.2 hectares. This superimposition of land structure and the evolution of the cadaster following the subdivision permit allow a first level of reading of the palimpsest (Corboz, 1993).

Almost exclusively residential, the allotments are comprised of villas and detached houses; most are singlestory and with occupied attic. Furthermore, if we look at the typo-morphological map of this area (Figure 5), more neighborhoods seem to be made up of separate villas, even though they are not included within allotment perimeters. An allotment permit is only needed when the owner wants to divide the land to subsequently sell it or build on it. Simple building permits are then not included in the allotments' dataset. Nevertheless, they could still be the result of a sale of de Merode's land, parcel per parcel, resulting from earlier subdivision.

Building these large landed properties in the 1960s greatly impacted the construction of an urban realm in 
Table 2. Selection of allotments in Rixensart.

\begin{tabular}{|c|c|c|c|c|c|c|c|c|c|}
\hline Name & Location & Owner(s) & Date & $\#$ & $\mathrm{Ha}$. & Estate cie. & Geom./Arch. & Delivering Authority & Prescriptions \\
\hline Léopold & $\begin{array}{l}\text { Avenue Léopold } \\
\text { Avenue du } \\
\text { Blanc Champ }\end{array}$ & $\begin{array}{l}\text { SA Matexi, } \\
\text { Van Coppenolle }\end{array}$ & $27-3-59$ & 30 & 3.2 & Matexi & Ernest Crickx & $\begin{array}{l}\text { Delegated official } \\
\text { (J. Wurth) }\end{array}$ & $\begin{array}{l}\text { Villas, bungalows, cottages. } \\
\text { Petrol pump or shop allowed } \\
\text { on an angle } \\
15 \mathrm{~m} \text { or } 20 \mathrm{~m} \text { wide plots } \\
\text { (depending on situation) } \\
\text { Setback }=6 \mathrm{~m}, 3 \text { m lateral } \\
\text { Limitation of felling trees }\end{array}$ \\
\hline $\begin{array}{l}\text { Fond Marie } \\
\text { Monseu }\end{array}$ & $\begin{array}{l}\text { Avenue } \\
\text { Marie-Christine, } \\
\text { rue Froidmont }\end{array}$ & SA Matexi & $16-7-62$ & 55 & 5.3 & Matexi & Ernest Crickx & $\begin{array}{l}\text { Delegated official } \\
\text { (L. Vanneste) }\end{array}$ & $\begin{array}{l}\text { Villas, cottages, bungalows. } \\
\text { H_cornice }=6 \mathrm{~m} \text {, pitched roof } \\
\text { Setback }=6 \mathrm{~m} \text { of which } 2 / 3 \\
\text { are planted and } 5 \mathrm{~m} \text { lateral } \\
20 \mathrm{~m} \text { wide plot } \\
\text { Road } 6 \mathrm{~m}+2 \times 2 \mathrm{~m} \text { sidewalk } \\
\text { Building materials limited }\end{array}$ \\
\hline Albertine & $\begin{array}{l}\text { Avenue Albertine, } \\
\text { Avenue Winston } \\
\text { Churchill } \\
\text { Rue de Limal }\end{array}$ & $\begin{array}{l}\text { Marquise de } \\
\text { Clermont- } \\
\text { Tonnerre }\end{array}$ & $16-04-62$ & 77 & 9 & Beteor SA & $\begin{array}{l}\text { Achille Dupuis } \\
\text { Georges de Halloy } \\
\text { André Gallée }\end{array}$ & $\begin{array}{l}\text { Delegated official } \\
\text { (J. Wurth) }\end{array}$ & $\begin{array}{l}\text { Detached villas or bungalows. } \\
\text { H_cornice }=5 \mathrm{~m} \\
\text { Setback }=6 \mathrm{~m} \text { minimum of } \\
\text { which } 2 / 3 \text { planted minimum } \\
\text { plot } 20 \times 15 \mathrm{~m} \\
\text { Shop allowed on the angles } \\
1.3 \mathrm{~m} \text { mandatory sidewalk in } \\
30 \times 30 \mathrm{~cm} \text { tiles }\end{array}$ \\
\hline
\end{tabular}


Table 2. (Cont.) Selection of allotments in Rixensart.

\begin{tabular}{|c|c|c|c|c|c|c|c|c|c|}
\hline Name & Location & Owner(s) & Date & $\#$ & Ha. & Estate cie. & Geom./Arch. & Delivering Authority & Prescriptions \\
\hline Froidmont & $\begin{array}{l}\text { Avenue de } \\
\text { Winterberg } \\
\text { (Ferme de } \\
\text { Froidmont) }\end{array}$ & $\begin{array}{l}\text { Chevalier J. } \\
\text { Demeure, } \\
\text { et indivision } \\
\text { Baron Dubost } \\
\text { Christian Delacroix } \\
\text { Christian Demeure } \\
\text { Edouard Demeure }\end{array}$ & $24-5-68$ & 273 & 30 & / & $\begin{array}{l}\text { Achille Dupuis } \\
\text { Georges de Halloy } \\
\text { André Gallée }\end{array}$ & $\begin{array}{l}\text { Permit refused by the } \\
\text { municipality to preserve } \\
\text { agricultural land, based } \\
\text { on the opinion of the } \\
\text { delegated official } \\
252 / F L / 27 . \\
\text { Legal recourse and } \\
\text { permit issuance by the } \\
\text { permanent deputation } \\
\text { of the province which } \\
\text { defines the area without } \\
\text { agricultural quality } \\
\text { (supported by agronomist } \\
\text { report) and of little } \\
\text { economic importance. It is } \\
\text { nevertheless asked to } \\
\text { preserve the rural character }\end{array}$ & $\begin{array}{l}\text { Villa or bungalow, single family } \\
\text { house, max } 200 \mathrm{~m}^{2} \\
1 \text { lot }(266) \text { reserved for a shop. } \\
\text { Setback }=6 \mathrm{~m} \text { of which } 2 / 3 \\
\text { are planted } \\
\text { H_Cornice = } 5.5 \mathrm{~m} \text { (manuscript } \\
\text { crossed out and replaced by } 3.5 \mathrm{~m} \text { ) } \\
\text { mandatory sidewalk } 30 \times 30 \mathrm{~cm} \text { tile } \\
\text { Utilities networks at the expense } \\
\text { of the purchasers, }+ \text { maintenance } \\
\text { of the roads during the works }\end{array}$ \\
\hline $\begin{array}{l}\text { Plateau } \\
\text { des } \\
\text { Bruyères }\end{array}$ & $\begin{array}{l}\text { Avenue des } \\
\text { Aubébines, } \\
\text { Paola, Fond } \\
\text { Marie Monseu }\end{array}$ & $\begin{array}{l}\text { D. de Lannoy, } \\
\text { M. de Lannoy, } \\
\text { P. Gillet (c/o } \\
\text { Cte Delannoy) }\end{array}$ & $19-6-64$ & 74 & 6.4 & / & Henri Souka & $\begin{array}{l}\text { permit delivered by } \\
\text { the municipality } \\
+ \text { opinion of } \\
\text { delegated official } \\
\text { (L. Vanneste) }\end{array}$ & $\begin{array}{l}\text { Single family house with } \\
\text { De Taeye Law requirement } \\
\left(\mathrm{min} 60 \mathrm{~m}^{2}\right) \\
\text { Setback }=6 \mathrm{~m} \text { of which } 1 / 2 \text { are } \\
\text { planted and } 5 \mathrm{~m} \text { lateral }\end{array}$ \\
\hline
\end{tabular}


Table 2. (Cont.) Selection of allotments in Rixensart.

\begin{tabular}{|c|c|c|c|c|c|c|c|c|c|}
\hline Name & Location & Owner(s) & Date & $\#$ & $\mathrm{Ha}$. & Estate cie. & Geom./Arch. & Delivering Authority & Prescriptions \\
\hline $\begin{array}{l}\text { Mare au } \\
\text { Loup }\end{array}$ & $\begin{array}{l}\text { Clos de la Mare } \\
\text { au Loup, } \\
\text { Avenue Boulogne, } \\
\text { Rue du Monastère }\end{array}$ & $\begin{array}{l}\text { Demeure André } \\
\text { Foncière de } \\
\text { développement SA. }\end{array}$ & $16-5-89$ & 38 & 9.7 & $\begin{array}{l}\text { Foncière de } \\
\text { développement SA. }\end{array}$ & $\begin{array}{l}\text { Georges de Halloy } \\
\text { Leleux, C. }\end{array}$ & $\begin{array}{l}\text { permit delivered by } \\
\text { the municipality, } \\
\text { asking to change } \\
\text { some road } \\
\text { configurations }\end{array}$ & $\begin{array}{l}\text { Single family house } \\
\text { Pitched roof } \\
\text { Setback }=6 \mathrm{~m}, 3 \mathrm{~m} \text { lateral } \\
\text { Building materials limited } \\
\text { Area covered by a schema } \\
\text { directeur PPA, indicating density } \\
\text { and contiguity requirements and } \\
\text { road/path network }\end{array}$ \\
\hline Haut taillis & $\begin{array}{l}\text { Avenue de } \\
\text { Villefranche, } \\
\text { Avenue des } \\
\text { Hauts Taillis }\end{array}$ & $\begin{array}{l}\text { Dumont de } \\
\text { Chassart }\end{array}$ & $7-7-69$ & 19 & 3.6 & B.C.I. sprl & $\mathrm{BCl}(?)$ & $\begin{array}{l}\text { permit delivered by } \\
\text { the municipality } \\
+ \text { opinion of } \\
\text { delegated official } \\
\text { (R. Beckers) }\end{array}$ & $\begin{array}{l}\text { Single family house }\left(\max 250 \mathrm{~m}^{2}\right) \\
\text { Setback }=6 \mathrm{~m} \text { of which } 1 / 2 \text { are } \\
\text { planted and } 5 \mathrm{~m} \text { lateral } \\
\text { Limitation of felling of trees } \\
\text { Building materials limited }\end{array}$ \\
\hline
\end{tabular}



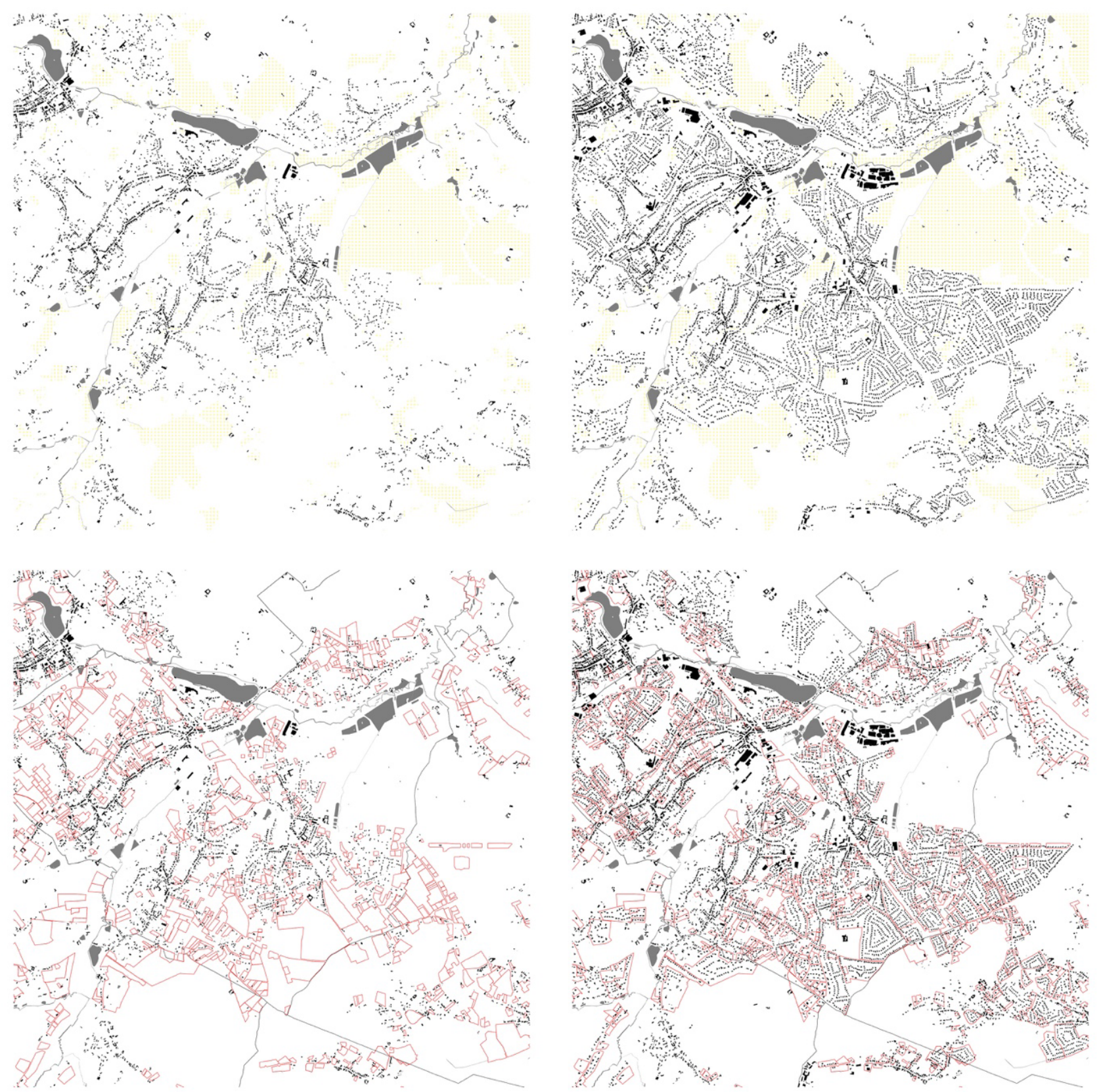

Figure 5. Map of Rixensart 1960 (left) and 2010 (right). Built elements (black), forest (yellow dots), water (grey), and allotments perimeter (red), municipal perimeter (dotted line). Elaborated by the author based on SPW-DG04 (2020).

Rixensart. The resulting urbanized patterns are mostly residential, erasing almost any other type of use or function (permits authorized some shops that were never built), offering quite a different environment than the one usually described for the nebulous Belgian city, resembling rather a typical periurban urbanization (Figure 6).

Nevertheless, under the apparent holistic process of transformation of land inherent to the allotment process, some territorial structures persist as traces in the patterns of the new development, remaining untouched as remnants (of a farm or monastery), fragments or a geometrical feature in the landscape (path, rural pattern, tree alignment). If division was part of the allotment act, the selling of and building on each parcel may have been a longer process, as shown by the variety of house styles, some of which are very recent.

In contrast, we should consider the preservation of some parcels that were neither sold nor built on and may have been a form, intentionally or not, of ecological protective measures. Mostly grouped around the de Merode Castle, some of the unbuilt plots are recognized as valuable natural areas such as Bois de Rixensart or Bois de Merode. Behind the land use and land ownership structure, several patrimonial, inheritance or economic decisions led to the current spatial configuration and the preserved areas today continue to be pressured. 

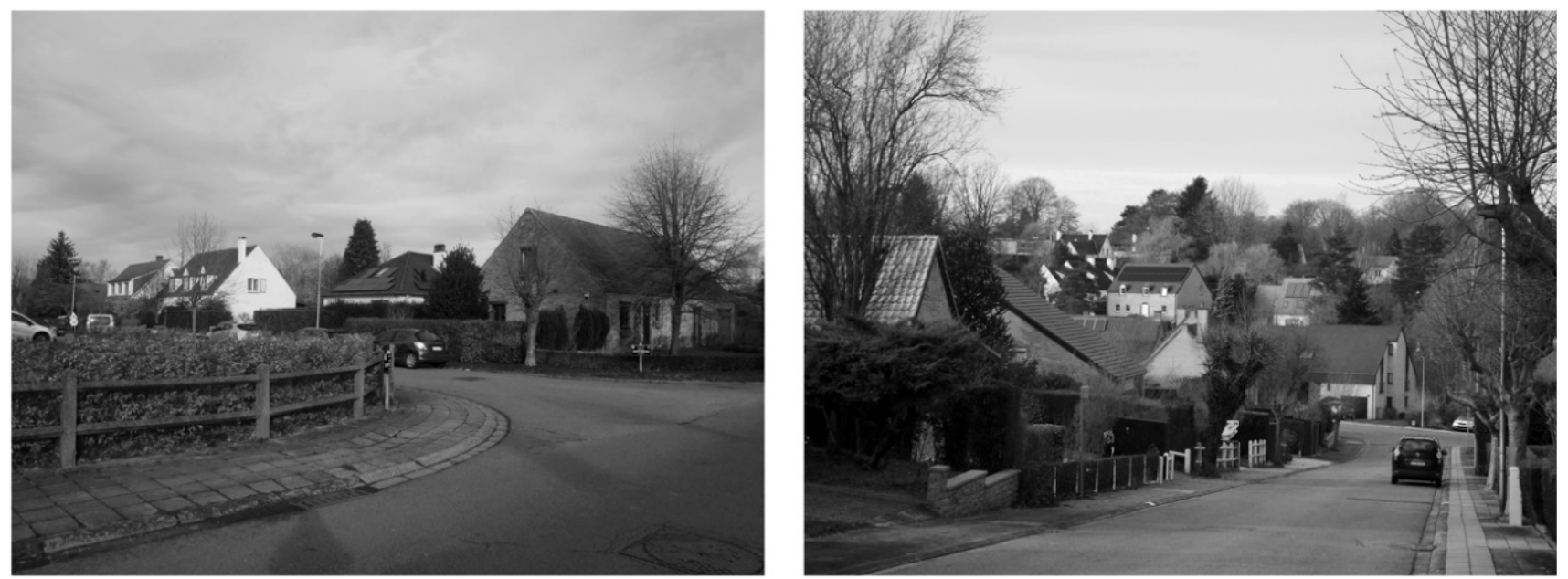

Figure 6. Urbanization in the Winterberg Avenue in Rixensart. Photographs by the author.

\section{Building the Material Condition of The City-Territory Urban Landscape}

\subsection{A Palimpsest of Actors}

To observe the urbanization produced on these large landholdings, we use the concept of the palimpsest mentioned above. In between the lines of the parcels, spaces of negotiation are recognizable and should be analyzed as part of rethinking our territorialities (Corboz, 1983, 1993). The concept of a palimpsest would not be of particular interest if it did not highlight the transformation of urban society through changing land structures (Vanneste, 2018). Through the multiple reading levels of the property concept (owner/ownership/property) and the land structure, we emphasize the relationships between land situation, uses, and value, which allow us to look at the production of space as intertwined with the agency of social and professional groups. Underneath this space of negotiation, we describe the urbanization produced in the specific socio-economic and urban context of Walloon Brabant.

Emphasizing the overlapping of actors involved is an additional approach to the idea of a palimpsest, enabling a territorialized vision of an urban society. In these processes of transfer of property, we scrutinize the actors' constellation behind elements of negotiation to envision the material conditions that supported the production of the urban landscape. Actors involved are witnesses of territorial changes in the ownership structure abruptly shifting from one long established situation with large dimensions' family estates with patrimonial value to one at the scale of middle-class owners marking the emergence of large-scale land commodification. In the middle is the real estate company, trading on the economic value of this ownership transfer. In this sense, this urbanization represents a discretized capital accumulation typical of post-war growth and the possibility for the housing market to absorb this surplus. This last palimpsest layer largely overwrites the former ones but is also largely conditioned by them.
In the case of Rixensart, this sequence of modification implying multiple actors occurred in the 1960s and 1970s and created the material and spatial conditions of urbanization. In the following step, we highlight the link between these actors and the material conditions of urbanization. Doing so, we relate the characteristics of the urbanization to the actors who took part in its construction voluntarily or not. Investigating these groups through a socio-spatial palimpsest clarifies what part of the urbanization belongs to the specific and successive transformation of large landholdings.

Let us browse these different groups. Letters and legal prescriptions attached to the subdivision permit listed previously make it possible to draw a portrait of the negotiation or opposition within the transfer of property and to what extent the delivering authority allows, refrains from or negotiates elements of the urbanization project. Which actors favored maintaining agricultural land? Which private or public actors pushed for more development and why? Who defined the dimension of the plot, streets, the proportion of built and open space? Ultimately, by whom and how were the material conditions of urbanization defined?

\subsection{Noble Estates}

Nobility owned land that remained mostly unbuilt. Estates were wooded and agricultural land. The successive division through inheritance processes reduced the size of de Merode land holdings but resulting plot size remained of large dimension. When sales started in the second half of the 20th century, the land structure inherited from the 19th century and their owners conditioned the dimension of the operation, enabling estate companies to buy, divide and sell quickly and consistently important pieces of land.

Recalling de Merode's strong influence on local governance and land ownership (through the estate steward and mayor), this fragmentation of nobility ownership could denote a loss or shift of influence domain. Nevertheless, some parcels still belonged to the fam- 
ily during the 1960s and most owner names still reflected those of noble family members, who were probably the heirs and inheritors belonging to different de Merode branches. In 2019 a more distant branch of the original de Merode family reinvested in the Rixensart Castle and its domain for patrimonial and touristic reasons by buying the castle of Rixensart (de Vogelaere, 2019). Therefore, large areas remain unbuilt, such as the Rixensart woods.

\subsection{Sales Operations, Administration, and Urban Grammar}

Sales operations involved a set of professional and private actors. Geometers, architects, resellers, and estate companies were to draw and conceive allotment plans for the municipal and provincial administration to analyze and authorize. Real estate companies were often present as operating actors in the process of dividing, selling, and building on the land. In two cases, the company itself was already the owner of the parcel in the permit document, implying that the parcel was sold in an earlier transaction, maybe not directly by the de Merode family.

What were the benefits of or the need for creating such companies? Couldn't the noble's family have sold themselves the land? Estate companies probably eased the management of repetitive and massive operations and outsourced a technical service. Incidentally, members of the nobility were still involved in the real estate companies, as reflected in allotment permit forms. Furthermore, they could help in inheritance procedures or just personify an economical tool to multiply subdivision operation, given we found companies involved on different allotment sites.

It was, however, not an innocuous operation. Resellers' financial interest and modern land use policy defined not only the plot's dimensions and repeatability and setback distances, but also the grammar of roads and house size and volume. Within the urbanization processes of these domains, decision-makers were indeed crucial actors in the precise definition of an urban grammar. Municipality, Walloon Region, and Walloon Brabant Province authorities and representatives had great decision-making responsibilities concerning parcel urbanization, or at least the type of product and urban fabric. When allotments were distributed, one of the representatives was Léopold Gilson, mayor from 1952 to 1970 and the last estate steward of the de Merode family, meaning the person in charge of managing the family's assets and estates.

\subsection{Territorial Base and Natural Features}

Unbuilt properties were mostly wooded or agricultural areas. One can see in analyzing the permit document that the neighborhood's character was discussed in an attempt to maintain a rural look and existing vegetation. Among the allotment dossiers, the agricultural value of the Winterberg Avenue allotments around the Froidmont Farm was a defense against the act of building (Figure 7). In 1962, the permit was refused by the municipality on the advice of the regional functionary, on the ground of defending valuable agricultural land and the landscape's rural character. To oppose the decision, the owner went to a higher court, at the provincial level. The province delivered the permit against the municipal decision, lessening the value of the agricultural land based on an agronomist's report, but, ironically, still asked the owner to maintain a rural character in the project's development. The case anticipates the problem of agricultural land consumption by urbanization, which today is a fundamental element of the European debate over 'no net land take,' aiming to reduce oversized residential areas of zoning plans.

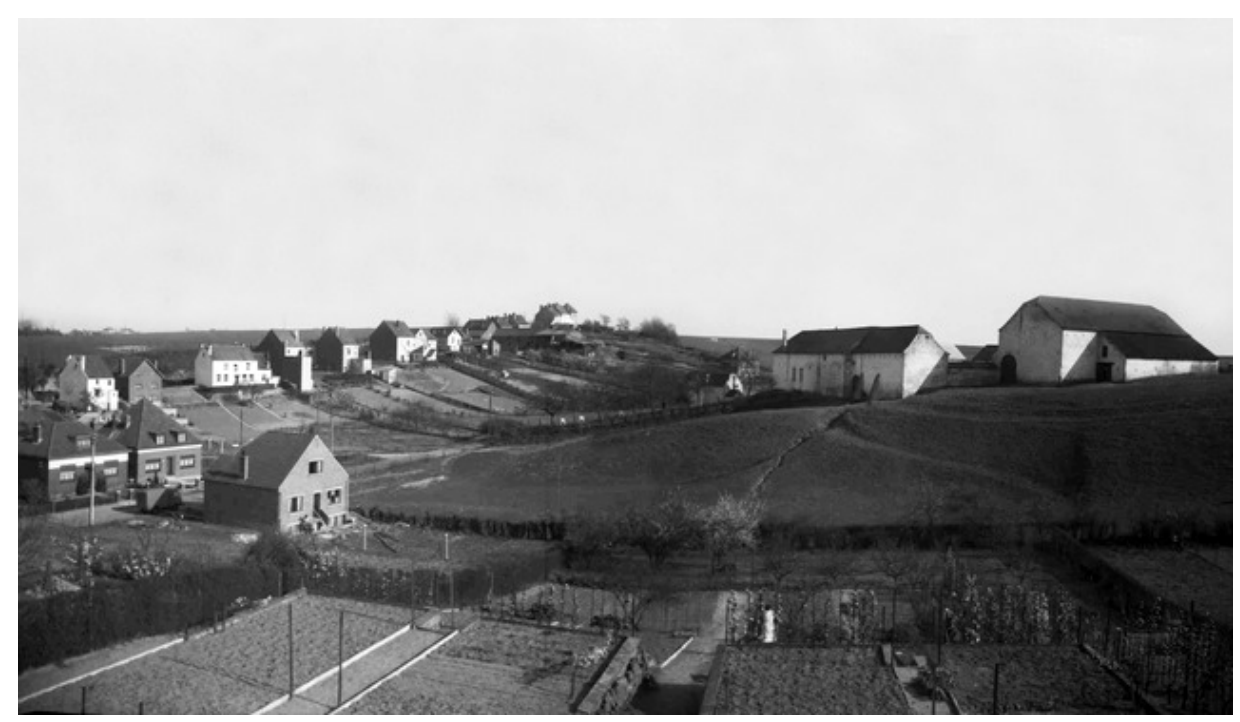

Figure 7. Neighborhoods of the Froidmont Farm in Rixensart. First houses under construction on Avenir Avenue, picture of H. Pilmeyer around 1954. Source: de Séjournet (2020a). 
Another key element in the prescriptions accompanying the building permit is the conservation of trees or limiting of tree felling. Indeed, in all the other cases, some previous natural or landscaped features, such as trees and onsite vegetation, are the subject of preservation requests as well, in whole or in part. Most of the sold land was wooded, part of former de Merode domains and remnants of the Sonian Forest. All legal prescriptions included preservation of wooded areas. If the documents provide no reason for it, one can assume the reasons are the trees' ecological value but also their symbolic value as being linked to the area's noble roots, conferring on certain parts of the neighborhood aspects of inhabited forest (Figure 8).

The defense of agrarian and natural characteristics, even in a sterile or picturesque manner, emphasizes a certain idea of living in an open landscape and foreshadows more ecological topics. The opposition between the institutional actors such as the province, the commune, and the regional functionary should be explored to understand each party's interests and if specific themes were defended or opposed regularly.

\subsection{Middle Class and Suburban Imaginaries}

Middle class families inhabited these new allotments, buying or building mainly single-family houses from the developer, being the end of line in the selling process we are describing. This generation embodied a way of life based on individual social and economic achievement embodied in the image of suburban villas. Through their purchase, they anchored Golden Sixties capital values in periurban landscapes. Some nuance is required to understand the operation's time span. While the transfer of properties and allotments of land ownership took place over a few decades, house construction reveals that the progressive development of the plots spans from the division of the land until today; some houses were still under construction in the 2000s. This prolonged period of construction gives the urbanization a heteroclite appearance: each house represents the aesthetics or building standards of its time.

Another recurrent regulatory requirement of the subdivision permits is plot dimensions, including setback distances. Surprisingly, setback distance is very consistent, six meters from the street, five to three meters from neighbors. Inner roads of the allotment are the developer's responsibility, then retroceded to the municipality. Quite often, the plot's buyer and future owner are responsible for the sidewalk, therefore taking part in responsibility for road infrastructure. Some basic compensation mechanisms force the developer to dedicate a small part of the area to green spaces or playgrounds. While setback distance allowed in latter phases for house additions or a backyard for each inhabitant, it is also a space of ambiguity, without real contiguity between neighbors kept at a distance and behind a green curtain of plants. The ambivalent permit requirement of urbanistic responsibility for the sidewalk constitutes equally a collective effort in the construction of the infrastructure as well as an absence of collectiveness, each inhabitant taking care of his or her own front space.

Ultimately, this in-between space creates an open and low-density fabric associated with garden cities,

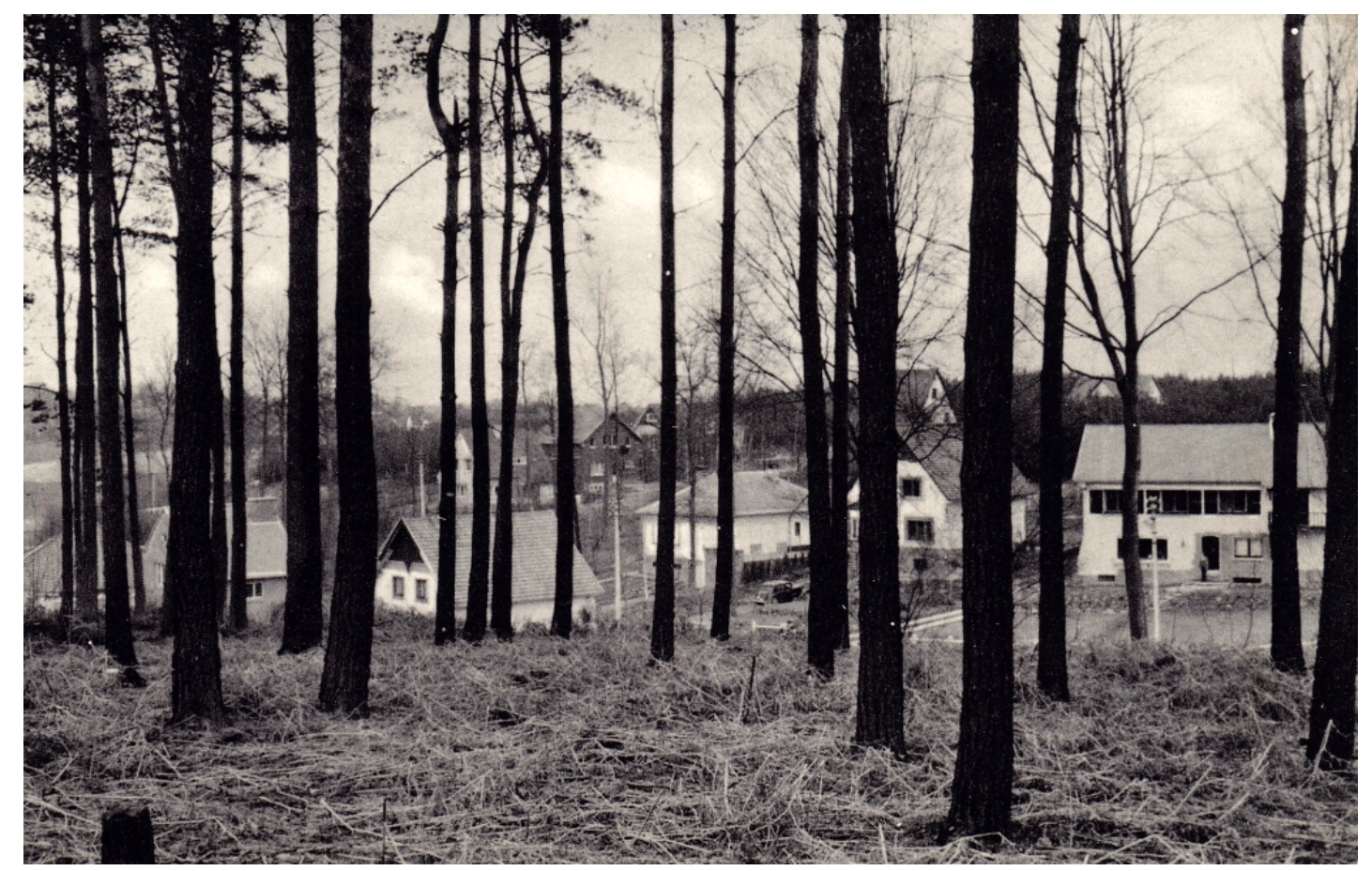

Figure 8. Wooded land built on through an allotment process. Avenue Joséphine-Charlotte, picture from the J.-L. Lebrun collection. Source: de Séjournet, E. (2020b). 
which were preeminent in a primary phase of modern development in Belgium; even though it ceased after a few experiments, the movement left an important imprint on housing imaginaries in Belgium (Smets, 1977, 1986). All in all, the urban fabric is characterized by a 'setback urbanization,' either physically by distancing the building, or conceptually by placing elements of infrastructure such as sidewalks or green areas under the responsibility of the individual rather than the collectivity.

\section{Conclusion}

Mapping the transformation of large domains and landed properties in Rixensart reveals dynamics of urbanization produced in a coherent socio-economic period of growth, on a territorial scale, in strong relation with the metropolization of Brussels. Timewise, the study case unfolded during a specific moment of post-war urbanization. Through the case of Rixensart we arrived at several findings addressing four main issues: metropolization on preexisting conditions, forms of urbanization (large dimensions with little collective arrangements), the relationships between actors (entrepreneurship and administration machine), and the regional condition of land ownership.

First, we argued that de Merode land subdivision processes-and, by generalization, large domains inherited from former feudal noble structures-had generated another type of urbanization when entering the buildable land market: not incremental, fragmented and mixed as predominantly observed in the industrial phases of urbanization that usually defines Belgium's dispersed urbanization, but rather large, functionalist, and homogeneous, which is typical of periurban metropolitan dynamics. The production of urbanization occurs on a larger scale than it did previously, although it still relies on dispersed features of the rural and pre-industrial territorial structure. In our case, the spatial configuration of the land ownership structure, embodied in the municipality's noble estates-relics of a fiefdom-and family relationships with municipal decision-makers allowed urbanization to occur.

Second, the large amount of available land made possible the settlement of a middle-class generation and the construction of its suburban imaginary. It resulted in the production of a quite consistent urban fabric, drawn up by 'setback urbanization' where individual freedom is embodied by each individual's plot but where, paradoxical to the plot's unifying morphology, no collective spatial dimension is fundamentally incorporated. It is striking to note the few but nevertheless existing nods to landscape or ecology in the urbanization process. Except from the case mentioned above, where the emergence of a conflict between buildable land value and natural or geographical land value, opposing economic and ecological value, is evident, the valorization of landscape or natural features only occurs at the level of the parcel, in each discretize and individual form. In another way, the absence of preservation or strong defense of natural or ecological land is also a lack of a collective dimension.

The case of Rixensart reflects strong links between nobility, industry, municipalism, and land ownership structures. The original approach to reading these relationships through a geography of actors offers a new perspective on recent forms of Walloon Brabant urbanization in a Belgian city-territory context. Indeed, the case reveals a period of strong municipal governance during which planning tools were very recent, permissive, and only in some cases opposed by higher authorities. We find the involvement of private entrepreneurship, as described in dispersed city conditions, but here on the broader scale of the allotments, with the involvement of developers and estate companies. Thus, not only the planning tools and administrative machine but also the private sales of powerful territorial actors form a web of relationships. In this sense, large domains are the receptacles of post-war socio-economic dynamics and national growth, which find an easy outlet in quickly accumulated land capital and lead to an urban morphological pattern of greater urbanization.

Furthermore, under the socio-spatial palimpsest of the Rixensart case, we uncovered a territorial condition of Walloon Brabant urbanization that proved to be related to large land ownership. This landed structure and availability of buildable land is strongly linked to the former power structure of ancien régime noble familiesand later of the industrial bourgeoisie. Several Walloon Brabant municipalities present a configuration similar to Rixensart's, where the permanence of land ownership and a genealogy of political management of the municipality coincide (Goblet d'Alviella and Boël in CourtSaint-Etienne, Vanderlinden d'Hoogvoorst in Ottignies, Solvay in la Hulpe, Cornet in Braine, etc.). As shown in the introduction, not all of these lands resulted in periurban urbanization, but most were transformed during the 20th century whether they became golf courses, business parks, or residential areas.

Revealing the actors and their interrelation with the urbanization of former estates brings a descriptive knowledge about the production of this specific space. Noble families, by owning large landholdings and selling them in large tracts, intervene in the size of the estate operation; discussion between estate companies and administrations about land use, landscape, and plot size defines the layout of the space; the middle-class population inhabiting these urbanizations generate architectural styles and picturesque gardens. After the fine descriptive period of the $80 \mathrm{~s}$ that described the horizontal and nebulous city, palimpsestic description today should testify to the complexity of city territory and spur thought regarding the future processes between metropolization and dispersion.

\section{Conflict of Interests}

The author declares no conflict of interests. 


\section{References}

Babar, L. (2015). Grande propriété foncière et développement urbain. Le cas bruxellois (XIXe-XXe siècle) [Large land ownership and urban development. The Brussels case (19th-20th century)] (Unpublished Doctoral dissertation). Université Libre de Bruxelles, Brussels, Belgium.

Bernard, N. (2017). L'article 17: Le droit de propriété [Article 17: The right of property]. In S. Van Drooghenbroeck \& F. Picod (Eds.), Charte des droits fondamentaux de l'Union européenne. Commentaire article par article [Charter of fundamental rights of the European Union. Commentary article per article ] (pp. 369-391). Brussels: Bruylant.

Corboz, A. (1983). Le territoire comme palimpseste [The land as palimpsest]. Diogène, 121, 14-35.

Corboz, A. (Ed.). (1993). Atlas du territoire genevois. Permanences et modifications cadastrales au XIXè et XXè siècles [Atlas of the Geneva territory. Permanences and cadastral modifications in the 19th and 20th centuries]. Geneva: Département des travaux publics du canton de Genève, Service des monuments et des sites.

De Block, G. (2011). Infrastructuur als inzet voor de organisatie van het territorium. Technologie, ruimte en maatschappij in België sinds het begin van de 19de eeuw [Engineering the territory. Technology, space and society in 19th and 20th century Belgium] (Unpublished Doctoral dissertation). KU Leuven, Leuven, Belgium.

De Block, G., \& Polasky, J. (2011). Light railways and the rural-urban continuum: Technology, space and society in late nineteenth-century Belgium. Journal of Historical Geography, 37(3), 312-328. https://doi. org/10.1016/j.jhg.2011.01.003

De Meulder, B., Schreurs, J., Cock, A., \& Notteboom, B. (2009). Sleutelen aan het Belgische stadslandschap [Patching up the Belgian urban landscape]. Oase: Tijdschrift voor Architectuur, 52, 78-113.

de Vogelaere, J.-P. (2019). Le château de Rixensart reste dans les mains de la famille de Merode [The castle of Rixensart remains in the hands of the de Merode family.; Press Release]. Retrieved from https://plus. lesoir.be/212215/article/2019-03-14/le-chateaude-rixensart-reste-dans-les-mains-de-la-famille-demerode

de Séjournet, E. (2020a). Froidmont, panoramique [Froidmont panoramic]. Retrorixensart. Retrieved from retrorixensart.com

de Séjournet, E. (2020b). Avenue Jospéhine-Charlotte [Joséphine-Charlotte avenue]. Retrorixensart. Retrieved from retrorixensart.com

Dehaene, M. (2013). Tuinieren in het Stedelijk Veld [Gardening in the urban field]. Gent: A\&S Books.

Dehaene, M. (2018). Horizontal metropolis: Issues and challenges of a new urban ecology statements. In P. Viganò, C. Cavalieri, \& M. Barcelloni Corte (Eds.), The horizontal metropolis between urbanism and urbanization (pp. 269-281). Cham: Springer.

Génicot, L. (Ed.). (1973). Histoire de la Wallonie [History of Wallonia]. Toulouse: Privat.

Grosjean, B. (2010). Urbanisation sans urbanisme, une histoire de la ville diffuse [Urbanization without urbanism, a history of the diffuse city]. Liège: Mardaga.

Grulois, G. (2011). La construction épistémologique de l'urbanisme en Belgique [The epistemological construction of town planning in Belgium]. Belgeo, 2011(1/2), 5-16. https://doi.org/10.4000/ belgeo.6329

Halleux, J.-M. (2013). Le gaspillage wallon [The Walloon waste]. Les Cahiers Nouveaux, 85, 13-15.

Hanin, Y. (2004). Mutations spatiales et recompositions territoriales. Les processus territoriaux dans le cas de Court-Saint-Etienne [Spatial changes and territorial recomposition. Territorial processes in the case of Court-Saint-Etienne] (Unpublished Doctoral dissertation). UCLouvain, Louvain-la-Neuve, Belgium.

Hanin, Y. (2012). Habiter en Wallonie: Évolutions, tendances et prévisions à l'horizon 2040 [Living in Wallonia: Developments, trends and forecasts up to 2040]. Les Cahiers Nouveaux, 84, 82-84.

Hasquin, H. (1976). Histoire, économie, sociétés. Tome 2: De 1830 à nos jours [History, economy, societies. Volume 2: From 1830 to the present day]. In $\mathrm{H}$. Hasquin (Ed.), La Wallonie. Le pays et les hommes [Wallonia, the land and the men] (Vol. 2, 1-529). Waterloo: La Renaissance du Livre.

Indovina, F. (1990). La città diffusa [The diffuse city]. Venice: Daest, Dipartimento di Analisi Economica e Sociale del Territorio.

Laconte, P. (2012). La loi du 29 mars 1962 sur l'urbanisme et ses effets: Quelques réflexions [The law of 29 March 1962 on town planning and its effects: Some thoughts]. Les Cahiers Nouveaux, 82, 34-39.

May, L. (2018). Suburban place-making: 'Place distinctiveness' as manifestation of political-economic coalitions: Antwerp, ca. 1860-ca. 1940. Paper presented at the "On reproduction: Re-imagining the political ecology of urbanism" Conference, Gent.

Meuwissen, E. (1994). Les grandes fortunes du Brabant. Seigneurs de la terre, Capitaines d'industrie [The great fortunes of Brabant. Lords of the Earth, captains of industry]. Ottignies: Quorum.

Meuwissen, E. (2016). Les Merode ou le syndrome de la peau de chagrin à Rixensart [The Merode or the fading to nothing syndrome at Rixensart]. Chroniques $d u$ cercle historique de Rixensart, 38.

Mougenot, C. (1999). La société nationale de la petite propriété terrienne. Une institution entre ville et campagne, entre tradition et modernization [The national society of small land ownership. An institution between town and country, between tradition and modernization.]. Les Cahiers Nouveaux, 1999(25/26), 145-148.

Peleman, D. (2013). "Les hommes de la route": Engineer- 
ing the urban society of the modern road in Belgium, 1889-1962. Ghent: Department of Architecture and Urban Planning.

Piccinato, G., Quilici, V., \& Tafuri, M. (1962). La città territorio: Verso una nuova dimensione [The city territory: Towards a new dimension]. Casabella, 270, 16-25.

Popp, P.-C. [ca. 1854]. Atlas cadastral parcellaire de Belgique [Cadastral parcel atlas of Belgium; Map]. Province de Brabant: Arrondissement de Bruxelles. Canton de Bruxelles. KBR, Brussels, Belgium. Retrieved from https://opac.kbr.be/library/maps-andplans.aspx?

Puissant, J. (1997). L'industrialisation du Brabant wallon et son impact sur l'urbanisation [The industrialisation of Walloon Brabant and its impact on urbanisation]. Les Dossiers Espace-Vie, 6, 35-42.

Ryckewaert, M. (2011). Building the economic backbone of the welfare state in Belgium. Infrastructure, planning and architecture 1945-1973. Rotterdam: 010 Publishers.

Secchi, B., \& Viganò, P. (2012). La métropole horizontale. [The horizontal metropolis] In P. Dejemeppe \& B. Périlleux (Eds.), Bruxelles 2040, trois visions pour une métropole [Brussels 2040, three visions for a metropolis] (pp. 29-45). Brussels: Éditions Région Bruxelles-Capitale.

Seebohm Rowntree, B. (1910). Land and labour. London: Macmillan.

Smets, M. (1977). L'avènement de la cité-jardin en Belgique, histoire de l'habitat social en Belgique 1830-1930 [The advent of the garden City in Belgium, history of social housing in Belgium 1830-1930]. Brussels: Mardaga.

Smets, M. (1986). La Belgique ou la banlieue radieuse [Belgium, or the radiant suburbs]. In Paysages d'architectures [Landscapes of architectures] (pp. 33-35). Brussels: F. d. l'architecture.

Smets, M. (Ed.). (1985). Resurgam. La reconstruction en Belgique après 1914 [Resurgam. Reconstruction in Belgium after 1914]. Brussels: Crédit Communal de Belgique.
SPW-DG04. (2018). Orthophotos 2018. Geo Portail. Retrieved from https://geoportail.wallonie. be/catalogue/71cb59f2-fb18-41bc-9dbf00ab93f69850.html

SPW-DG04. (2020). Lotissements (LOT). Geo Portail. Retrieved from http://geoportail.wallonie. be/catalogue/4572f901-7d5e-4fe6-931eac19c8fc04fe.html

Theunis, K. (2007). De zoektocht naar een Belgisch woonproject, 1965-1975. Toenaderingen tussen ontwerpers en overheid in de praktijk van het private wonen [The search for a Belgian housing project, 1965-1975. Approaches between designers and government in the practice of private housing] (Unpublished Doctoral dissertation). KU Leuven, Leuven, Belgium.

Uyttenhove, P. (2011). Stadland België, hoofdstukken uit de geschiedenis van de stedenbouw in België [Stadland Belgium, chapters in the history of urbanism in Belgium]. Gent: A\&S Books.

Vandervelde, E. (1900). La propriété foncière en Belgique [Land ownership in Belgium]. Paris: Schleicher Frères éditeurs.

Vanneste, G. (2018). Territory between product and project: Rethinking the limits. In P. Viganò, C. Cavalieri, \& M. Barcelloni Corte (Eds.), The horizontal metropolis between urbanism and urbanization (p. 422). Cham: Springer.

Vanuxem, S. (2018). La propriété de la Terre [The ownership of the land]. Marseille: Wildproject.

Vrielinck, S. (2018). Grootse Plannen. De Kadastrale Atlas Van België Van P. C. Popp: Genese En Datering (1840-1880) [Great plans. The cadastral atlas of Belgium by P. C. Popp: Genesis and dating (1840-1880)]. Amsterdam: Amsterdam University Press.

Wambecq, W. (2019). Forest urbanism in the dispersed Flemish territory (Unpublished Doctoral dissertation). KU Leuven, Leuven, Belgium.

Zitouni, B. (2010). Agglomérer! Une anatomie de l'extension bruxelloise (1828-1915) [Agglomerate! An anatomy of the Brussels extension (1828-1915)]. Brussels: Brussels University Press.

\section{About the Author}

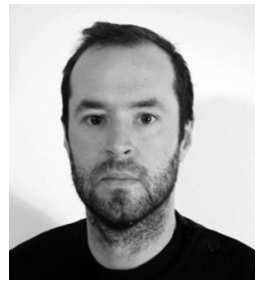

Guillaume Vanneste graduated as an Engineer Architect from the EPL UCLouvain in 2009, and a Research and Teaching Assistant and PhD from LOCl-Faculty of Architecture, Architectural Engineering and Urban Planning at UCLouvain. His actual research explores the production of contemporary city-territory landscape and land structure in the Belgian dispersed urbanization. Unfolding the case of Brabant from the issue of land ownership and land structure helps deepening the understanding of contemporary situation in urbanism. 